\title{
ASSESSING SHORELINE CHANGE USING SATELLITE-DERIVED SHORELINES IN PROGRESO, YUCATÁN, MÉXICO
}

\author{
Gabriela García-Rubio ${ }^{1}$, David Huntley ${ }^{2}$ and Paul Russell ${ }^{3}$.
}

\begin{abstract}
Assessment of shoreline change during a six-year period using Satellite-Derived Shorelines (SDS) was carried out in Progreso, Yucatán, México. Confidence bounds for the SDS were defined based on the deviation between quasisimultaneous in situ shoreline measurements and SDS. The main objective of this paper is to show that optical satellite images are a valuable resource to study shoreline change covering large geographical scales $(>10 \mathrm{~km})$, as well as short ( $<1$ month) and long ( $>5$ years) temporal scales. This approach can be particularly useful for those areas with a lack of shoreline records. The results presented here show that detection of differences between seasons and years is achievable using SDS. Furthermore, rates of change are also possible to assess.
\end{abstract}

Keywords: coastal monitoring; satellite optical images; coastal erosion; coastal management.

\section{INTRODUCTION}

Shorelines are features vulnerable to erosion, floods, storms and hurricanes. They are inherently dynamic features that mark the transition between land and sea. Shorelines change their location over time, and at different spatial scales due to waves, winds, nearshore currents, storms and by human modification. It is estimated that there are more than $347,984 \mathrm{~km}$ of shoreline in the world and that $60 \%$ of the world's population lives within $100 \mathrm{~km}$ of the sea (Vitousek et al. 1997). In addition, considering the sea level rise produced by climate change, monitoring shoreline change becomes particularly relevant as well as assessment of shoreline erosion and coastal flooding (Douglas et al. 2001; FitzGerald et al. 2008; Gutierrez et al. 2011). Shoreline erosion and coastal flooding were highlighted among the gravest effects of climate change by the IPCC (1990). Within this context, the shoreline has been also recognised as one of the 27 global geo-indicators referred to by the International Union of Geological Science for shoreline change monitoring (Li et al. 2003). The implementation of coastal monitoring and shoreline change studies is costly and beyond human and budget capacities for developed and developing countries. Therefore, to monitor shoreline change covering large spatial scales, a cost-effective approach is required, particularly for those places where there are concerns about shoreline erosion, paucity of coastal data and/or limited access to carry out in situ shoreline measurements on a regular basis.

The objective of this research is to show that optical satellite images are a valuable resource to assess shoreline change, as well to investigate the factors that could have been involved in the observed shoreline change.

Besides satellite imagery, there are multiple data sources that can help to identify the shoreline, such as aerial photography, radar, video and field surveying techniques. Optical satellite images have been widely used to map the shoreline, offering the potential to update maps systematically covering large areas as often as every one to eight days (Frihy and Lotfy 1997). The spatial resolution of optical satellite images has been improving in the last 20 years, from $20 \mathrm{~m}$ to $0.4 \mathrm{~m}$ pixel size, allowing access to images with a much better resolution and offering the possibility of building a long database (>20years) to study shoreline change in places where otherwise the shoreline would not be monitored.

Optical satellite images have been previously used to study shoreline change (Mason et al. 1995; Chen and Rau 1998; White and El-Asmar 1999; Li et al. 2003; Liu and Jezek 2004; Muslim et al. 2006; Dinesh-Kumar et al. 2007; Li et al. 2008; Wang et al. 2010), showing their value in coastal studies. However, for their use it is essential to take into consideration the beach characteristics as well as the oceanographic conditions.

Optical satellite images measure the reflected sunlight from the Earth's surface (Robinson 2004). Thus, shoreline identification is based on the optical contrast between the sea and the land. So, for shoreline identification, where the shoreline is defined as the intersection between the sea and the land, consideration of water levels (tides, wave set-up and wave run-up) when the satellite passed over the study area is required. Furthermore, the shoreline location will vary according to the beach

\footnotetext{
${ }^{1}$ CICESE, Km. 105 carretera Ensenada-Tijuana No.3918, Zona Playitas, c.p. 22860, Ensenada, B.C. México.

${ }^{2}$ Plymouth University, Drake circus, Plymouth, Devon, PL48AA, United Kingdom.

${ }^{3}$ Plymouth University, Drake circus, Plymouth, Devon, PL48AA, United Kingdom.
} 


\section{COASTAL ENGINEERING 2012}

morphology. For example, in high tide conditions, the shoreline location will be landwards over a shallow inter-tidal beach slope in relation to a steeper inter-tidal beach slope.

This study assesses shoreline change using Satellite-Derived Shorelines (SDS) considering the beach morphology and water levels. The analysis of SDSs in this region helped to estimate the intra-annual and inter-annual shoreline change in a 6.5 year period (December 2003 to July 2010). Shoreline change larger than 20m was found, as well as point locations with changes as large as 100 metres. Moreover, it was found that Progreso has overall erosion with a shoreline rate of change between $-2.4 \mathrm{~m}$ and $-1.2 \mathrm{~m}$ per year. The assessment of SDSs shows the value of exploring shoreline change using SDS and demonstrates their applicability at similar locations.

\section{METHOD}

\section{Shoreline identification}

Shorelines were extracted from the available optical satellite images covering Progreso from the SPOT satellite. The images used are multispectral with a $10 \mathrm{~m}$ pixel size and a pre-processing level $2 \mathrm{~A}$. The satellite image was geometrically corrected using in situ Ground Control Points (GCP), ensuring for all cases a root mean square error smaller than half the pixel size $(<5 \mathrm{~m})$ between the GCP and the corresponding point locations in the image. By following this procedure it was ensured that all images were geometrically corrected using the same geometric reference and an error of similar magnitude (White and El-Asmar 1999).

The shoreline identification is based on grouping all the pixels from the image into two contrasting classes, sea and land. The grouping of both classes was achieved using a non-supervised classification. The non-supervised classification has shown robust results for identifying wet and dry pixels (Foody et al 2005, Muslim et al 2006, Dinesh-Kumar et al 2007).

The output from the classification process is an image with pixels grouped either as sea or land. The boundary between land and sea in the classified image is converted into a vector. The resulting vector requires a manual edit whereby the inland features not related to the shoreline are removed using ArcGIS software. The result is a stepped vector that follows the boundary between the pixels classified as sea and land. The final vector is smoothed to remove the jagged pattern produced by the pixels' location, and can then be compared with other shorelines. Because the location of the shoreline depends on the tidal level at the time when the satellite passed the study area, the shoreline position has to be adjusted to a specific tidal datum.

In this research all SDSs are referred to an equal tidal datum (MLLWL), based on predicted tidal levels due to a lack of consistent measured tides in Yucatán. The tidal level of each SDS was estimated using the local time when the satellite passed over the study area. So, when the images had different tidal levels than the tidal datum, the shoreline position was adjusted using the inter-tidal beach slope as a reference (Figure 1).

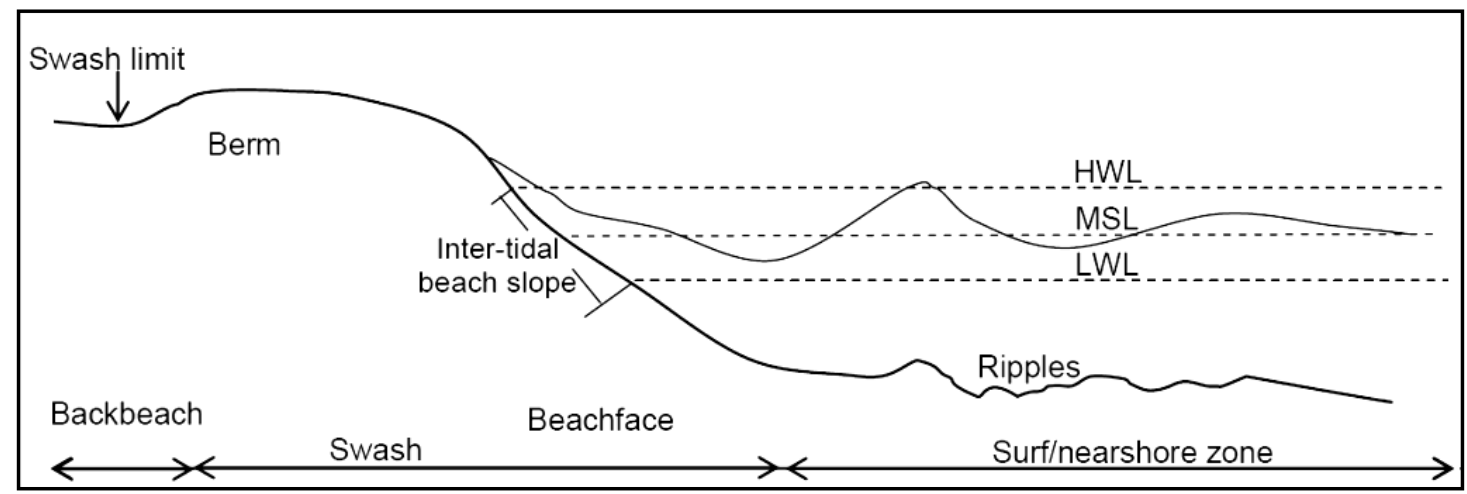

Figure 1. Diagram showing a typical beach profile. The inter-tidal beach slope has been used to adjust the shoreline position at an equal tidal datum (MLLWL). 


\section{COASTAL ENGINEERING 2012}

Confidence bounds for the SDS were defined based on the previous validation of this technique using quasi-simultaneous in situ shoreline measurements with the optical satellite image. The confidence bounds consider the horizontal excursion produced by the wave run-up, and the uncertainty due to the use of tidal predictions rather than using tidal measurements (García-Rubio 2012).

\section{Shoreline change assessment}

Shoreline change assessment covered 13 images from different seasons during a 6 year period. Table 1 details their temporal spacing, as well as the presence of cyclones or extreme events that could have had an effect on the observed shoreline position.

\begin{tabular}{|c|c|c|}
\hline $\begin{array}{c}\text { Date } \\
\text { (dd/mm/yyyy) }\end{array}$ & Season & Env. conditions \\
\hline $12 / 07 / 2010$ & Hurricane & $\begin{array}{c}\text { The } 2009 \text { hurricane season was not very active. One hurricane } \\
\text { passed close to Yucatán from Nov. } 4 \text { to } 10 . \text { On the } 8^{\text {th }} \text { it was at its } \\
\text { closest to Yucatán (approx. } 370 \mathrm{~km} \text { ), holding winds of } 160 \mathrm{kmh}^{-1} \text { and } \\
\text { atm. pres. of } 976 \mathrm{hPa} \text {. }\end{array}$ \\
\hline $20 / 09 / 2008$ & Hurricane & $\begin{array}{c}\text { H lke passed close to Yucatán at approximately } 500 \mathrm{~km} \mathrm{NE} \text {, with } \\
\text { intensity as cat. } 1 \text {, with winds of } 56 \mathrm{kmh}^{-1} \text { and } 957 \mathrm{hPa} \text { of atm. press. } \\
\text { on the } 10^{\text {th }} \text { of September, then moved north to Galveston, Texas, } \\
\text { where it had its main landfall. }\end{array}$ \\
\hline 05/09/2007 & Hurricane & $\begin{array}{c}\text { TS Alberto passed close to Yucatán on Jun. 8, 2006. In 2007, } \mathrm{H} \\
\text { Dean crossed Yucatán from the eastern to the western coast with an } \\
\text { intensity of cat. 2, with winds of } 168 \mathrm{kmh}^{-1} \text { and } 950 \mathrm{hPa} \text { of atm. } \\
\text { press. }\end{array}$ \\
\hline $06 / 02 / 2006$ & Winter & $\begin{array}{l}\text { The } 2005 \text { hurricane season was the most active on record. Four } \\
\text { cyclones passed close to Yucatán: } \mathrm{H} \text { Rita, } \mathrm{H} \text { Wilma, } \mathrm{H} \text { Stan and } \mathrm{H} \\
\text { Katrina. H Rita passed at approx. } 500 \mathrm{~km} \text {, with intensity of cat. } 5 \text {, } \\
\text { winds of } 264 \mathrm{kmh}^{-1} \text { and atm. press. of } 914 \mathrm{hPa} \text {. H Wilma passed at } \\
\text { approx. } 280 \mathrm{~km}^{-1} \text { on Oct. } 22 \text {, with intensity of cat. } 2 \text {, winds of } 160 \\
\mathrm{kmh}^{-1} \text { and atm. press. of } 957 \mathrm{hPa} \text {. } \mathrm{H} \text { Stan passed at approx. } 80 \mathrm{~km} \text {, } \\
\text { as TS, holding winds of } 64 \mathrm{kmh}^{-1} \text { and atm. pres. of } 1004 \mathrm{hPa} \text {. } \mathrm{H} \\
\text { Katrina passed at approx. } 544 \mathrm{~km} \text { with intensity of cat. } 4 \text {, winds of } \\
230 \mathrm{kmh}^{-1} \text { with atm. press. of } 955 \mathrm{hPa} \text {. }\end{array}$ \\
\hline $30 / 07 / 2005$ & Hurricane & $\begin{array}{l}\text { H Emily passed at approx. } 90 \mathrm{~km} \text { from Yucatán as cat. 2, winds of } \\
160 \mathrm{kmh}^{-1} \text { and an atm. press. of } 975 \mathrm{hPa} \text {. }\end{array}$ \\
\hline $17 / 07 / 2005$ & Hurricane & $\begin{array}{l}\mathrm{H} \text { Arlene passed at approx. } 540 \mathrm{~km} \text { from Yucatán, winds of } 72 \mathrm{kmh}^{-1} \\
\text { with atm. press. of } 1000 \mathrm{hPa} \text {. }\end{array}$ \\
\hline $04 / 04 / 2005$ & Calm & There is no evidence of any storm. \\
\hline $20 / 03 / 2005$ & Calm & There is no evidence of any storm. \\
\hline $15 / 11 / 2004$ & Winter & No hurricanes passed close to Yucatán. \\
\hline $27 / 09 / 2004$ & Hurricane & $\begin{array}{l}\text { TS Bonnie, approx. } 240 \mathrm{~km} \text { from Yucatán, with winds of } 72 \mathrm{kmh}^{-1} \text { and } \\
\text { an atm. press. of } 1007 \mathrm{hPa} \text {. } \mathrm{H} \text { Charley, approx. } 800 \mathrm{~km} \text { from Yucatán } \\
\text { with intensity of cat. } 2 \text { with winds of } 168 \mathrm{kmh}^{-1} \text { and atm. press. of } 975 \\
\mathrm{hPa} \text {. A surge of } 3.9 \mathrm{~m} \text { in Playa Cajio, Cuba was reported on Sept. } 13 \\
\text { (NHC 2010). H Ivan, approx. } 256 \mathrm{~km} \text { from Yucatán on Sept. } 14 \text {, with } \\
\text { intensity of cat. } 5 \text { with winds of } 256 \mathrm{kmh}^{-1} \text { and atm. press. of } 924 \\
\mathrm{hPa} \text {. }\end{array}$ \\
\hline $25 / 06 / 2004$ & Hurricane & No hurricanes passed close to Yucatán. \\
\hline $20 / 05 / 2004$ & Calm & $\begin{array}{l}\text { The wave record from Dec. } 30^{\text {th }} \text { to May } 19^{\text {th }} \text { has on average Hs of } \\
0.26 \mathrm{~m} \text {, with max. of } 0.35 \mathrm{~m} \text { measured in Progreso, } 4 \mathrm{~km} \text { offshore. }\end{array}$ \\
\hline $23 / 12 / 2003$ & Winter & $\begin{array}{l}\text { Hs of } 0.32 \mathrm{~m} \text { and max. of } 0.57 \mathrm{~m} \text { measured in Progreso, } 4 \mathrm{~km} \\
\text { offshore from the pier, from Nov. } 11^{\text {th }} \text { to Dec. } 20^{\text {th }}\end{array}$ \\
\hline
\end{tabular}

The available images over a two-year period (2004 to 2005) cover different seasons, so, they were used to estimate the average shoreline and assess the intra-annual and inter-annual shoreline change. The shoreline change was assessed covering $8 \mathrm{~km}$ of shoreline (Figure 3, Table 2).

The inter-annual shoreline change has been assessed using the alongshore averages of the northerly position of each SDSs for each beach segment. The average of the northerly position was chosen as the shoreline mostly runs east to west. Although, the northerly shoreline position is not at a precise right angle at all the point locations, the alongshore average would decrease the variation within each beach segment. 
The rates of change were estimated using a linear regression, adjusting the alongshore averages over time into the line of best fit. So, the rates of change were estimated using the slope of the adjusted line. The rates of change are the result of the temporal spacing during the study period. In other words, they could change when more shoreline locations are included into the analysis.

\section{STUDY AREA}

\section{General description}

The case of study is located in Progreso, Yucatán, México. Yucatán has a typically shallow bathymetry $(1: 1,000)$ and a wide continental shelf, exceeding $100 \mathrm{~km}$ (Figure 2). The direction of the waves travelling onshore over such a shallow bathymetry is likely to be mainly determined by the wind direction. Measured waves at $10 \mathrm{~m}$ depth confirmed that the waves have short periods, smaller than $5 \mathrm{~s}$ (Mariño-Tapia 2010). The wind direction in Yucatán is dominated by the Trade winds (NE). The wave and wind direction is similar, with a dominant direction through the year from the E-NE with variations in winter and summer.

The tide in the study area is diurnal, with a form factor (F) larger than 3 (4.8), indicating that the diurnal constituents are more important than the semidiurnal constituents (Pugh 2004). The tidal range is considered to be microtidal, with a maximum tidal range of $0.9 \mathrm{~m}$ during spring tides and less than $0.2 \mathrm{~m}$ during neap conditions.

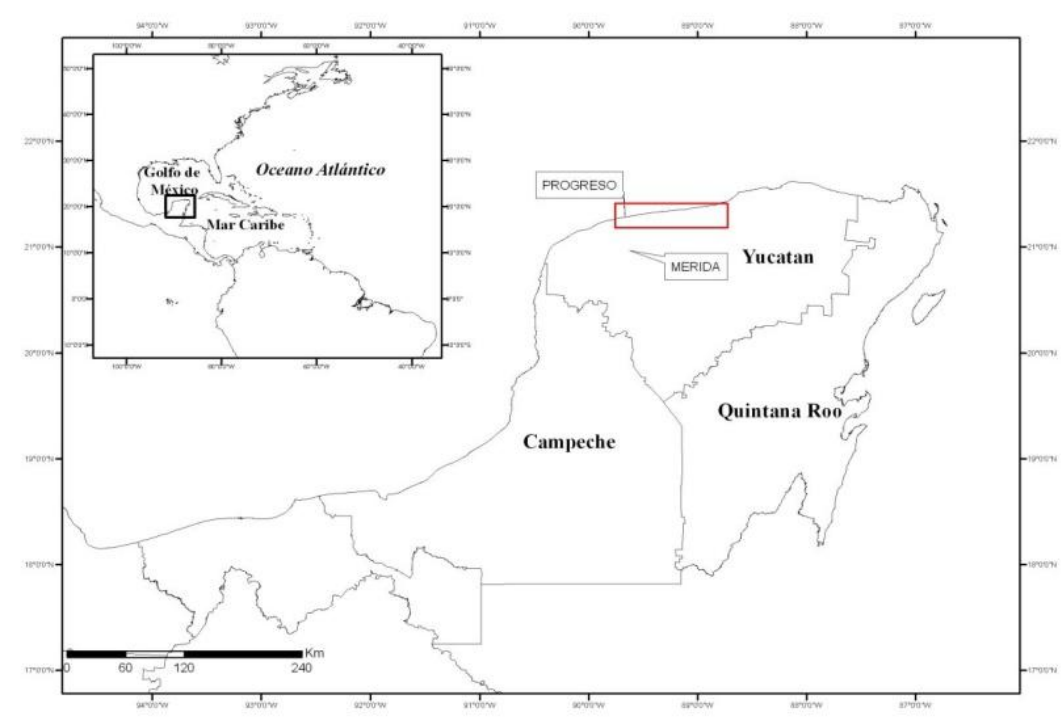

Figure 2. Geographical location of Yucatán, México, within the continent (top left). Close up within the black square, showing the location of the case of study of Progreso, Yucatán.

\section{Hurricanes}

The potential for hurricanes in the case study area is a constant threat. Although is not possible to predict whether hurricanes will pass close to the study area, the analysis of long records of hurricane tracks gives an estimate of which months have a higher likelihood of occurrence.

Hurricanes Gilbert (1988) and Isidore (2002) did directly impact on the Yucatán Peninsula causing a widespread damage. Hurricane Gilbert, H5, crossed the Yucatán Peninsula from east to west. The estimation of the surge levels was between four and six metres at the immediate coast near the hurricane. Two hundred people were reported dead and over 60,000 houses were damaged in the country (NHC 1988). During Hurricane Isidore, the opening of inlets took place at about $60 \mathrm{~km}$ east from Progreso. 


\section{Longshore transport}

The usual scenario is wind generated waves approaching from NE, driving a westward longshore transport. Regardless of the lack of direct field measurements of the longshore transport, field observations show constant accumulation of sand east of the groynes, suggesting a westward dominant drift direction that agrees with the dominant wind direction and observations of Appendini et al (2012).

\section{Beach modification}

The beach modification in Yucatán started in 1947 with the construction of Progreso's pier. Initially, the pier was $2 \mathrm{~km}$ long but it later had two extensions: the first to $4 \mathrm{~km}$ and the second to $8 \mathrm{~km}$, as it remains today. The setting and removal of groynes along the shoreline is commonplace. During the 1990s, an uncontrolled number of groynes were set by householders in an attempt to retain the beach in front of their properties, without considering the consequences to the vicinity. An aerial survey in Progreso from 1984 shows the presence of 178 jetties along 8.8km of shoreline (Meyer-Arendt 2001). Due to a large number of groynes set in an anarchic way, by 2005 the local council removed all groynes due to increased erosion. Instead, geotextile and reefballs were installed to protect vulnerable areas from further retreat. After five years, the expected beach recovery has not occurred (AXIS 2008).

\section{Beach characteristics of the study area}

Figure 3 shows the case study area that locates in Progreso covering $8 \mathrm{~km}$ of shoreline. For the purpose of this study, the shoreline was divided into eight beach segments according to their morphology. In this paper only the results of segments 3 and 8 are shown. Detailed results including the $8 \mathrm{~km}$ of shoreline will be shown in future work.

Table 2 summarises the beach characteristics for the beach segments identified in Progreso. Segment 4 includes the two piers from Progreso, one $8 \mathrm{~km}$ long and the other $2 \mathrm{~km}$. Segments 3 and 5, located next to the pier, are directly influenced by the pier. The differences within the east and west beach segments are mostly related to their distance from the pier.

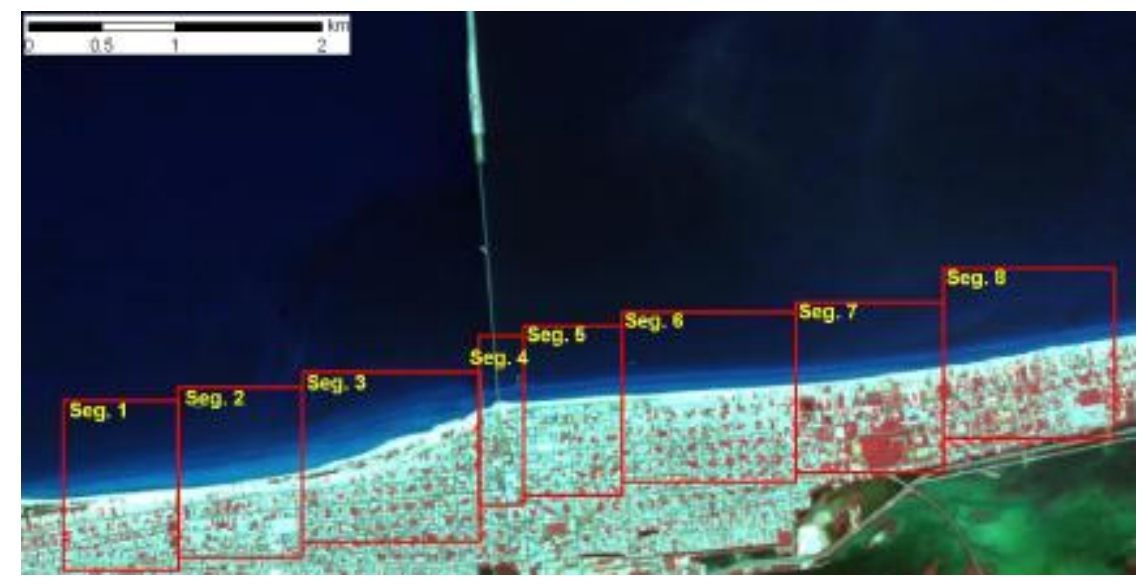

Figure 3. Beach segments used in the case study area of Progreso, Yucatán. Segment 4 includes Progreso' pier and a second pier located in between segment 3 and segment 4.

\begin{tabular}{|c|c|c|c|c|c|c|c|c|}
\hline & West & & & & & East & & \\
\hline & Seg. 1 & Seg.2 & Seg. 3 & Seg.4 & Seg. 5 & Seg.6 & Seg. 7 & Seg. 8 \\
\hline$\alpha$ & 5 & 8 & 18 & 27 to -2 & 3.1 & 3.7 & 6.8 & 9.7 \\
\hline$\beta$ & 3 & 5 & 5 & 9 & 6 & 6 & 5 & 5 \\
\hline $\begin{array}{l}\text { Beach } \\
\text { width }(\mathrm{m})\end{array}$ & 80 & 50 & 178 & 15 & 30 & 52 & 25 & 23 \\
\hline $\begin{array}{l}\text { X grain size } \\
(\mathrm{mm})\end{array}$ & 0.22 & 0.26 & 0.24 & 0.61 & 0.34 & 0.28 & 0.52 & 0.84 \\
\hline $\begin{array}{l}\text { Coastal } \\
\text { vegetation }\end{array}$ & Yes & Yes & Yes & No & No & No & No & No \\
\hline $\begin{array}{l}\text { Coastal } \\
\text { structures }\end{array}$ & No & No & No & Yes & No & No & No & No \\
\hline Length (m) & 810 & 810 & 1,300 & 310 & 680 & 1,185 & 1,000 & 2,280 \\
\hline
\end{tabular}




\section{COASTAL ENGINEERING 2012}

\section{RESULTS}

\section{Confidence bounds}

Although estimation of confidence bounds for SDS is a topic under development, an attempt is presented in this paper to improve shoreline change estimates when using optical satellite images. The confidence bounds were determined using the horizontal deviation between the SDS and the in situ shoreline measurements. The inter-comparison showed that the deviation between the SDS and the in situ shoreline measurements are smaller than $3 \mathrm{~m}$. The wave run-up in the region is between 0.2 and $0.4 \mathrm{~m}$ height. On a beach with an inter-tidal slope of $6^{\circ}$, the wave run-up will cause a shorewards excursion between $2 \mathrm{~m}$ and $4 \mathrm{~m}$.

Table 3 shows the estimated confidence bounds for each beach segment. Considering the shorewards and seawards movement of the shoreline, the magnitude of the deviation is in agreement with the estimated horizontal excursion of the wave run-up. There was no available information that allowed us to define the environmental conditions when the satellite passed over the case study area. However, there were no records of cyclones or storms when the satellite passed over the case study area. So, the same confidence bounds were applied for all the analysed SDSs.

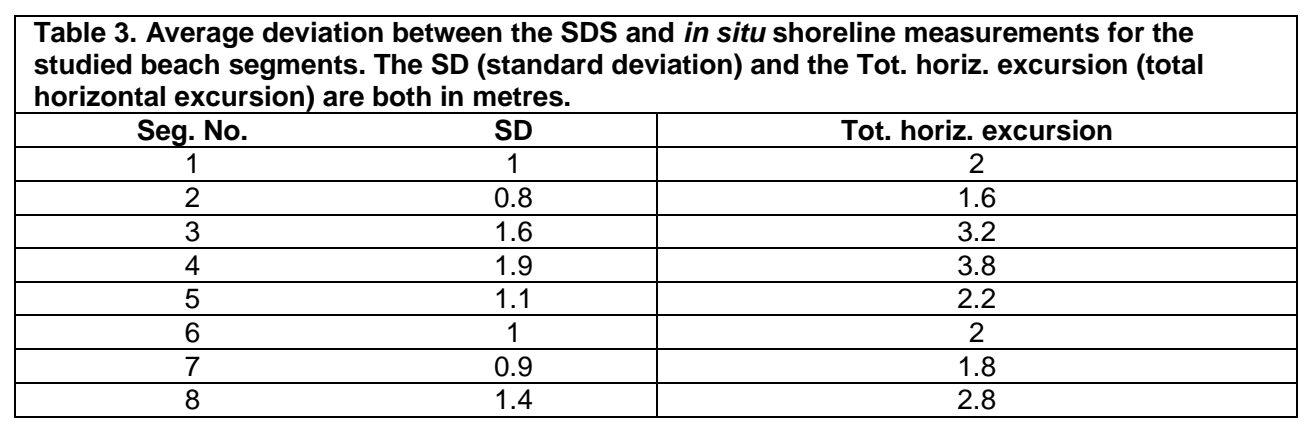

\section{Shoreline change}

Figures 4 and 5 show the observed horizontal change in the corrected shoreline location from December 2003 to July 2010 in beach segments 3 and 8 respectively. The observed shoreline change in segment 8 is different than that observed in segment 3 . First, the shoreline change is relatively homogeneous in the alongshore. Second, a SDS during the storm season (November 2004) is located further seawards than the rest of the shorelines, contrary to that observed in segment 3 . Third, overall the shoreline seems to be moving shorewards over time.

\section{Intra-annual changes}

\section{Hurricanes}

The analysed SDSs allowed shoreline change detection due to hurricanes. SDSs for segment 3 showed a large variation in their shoreline location, particularly towards the east (approx. $200 \mathrm{~m}$ from Progreso's pier). Such a long pier as Progreso, with a shore-parallel structure at its end, modifies the alongshore gradient of sediment. The observed changes in the shoreline location suggest that the sand is trapped next to the pier and that during extreme events the sand can be moved.

Figure 4 shows that the SDSs from late in the hurricane season (September and November, 2004) are significantly landwards in relation to the SDSs from the early start of the hurricane season (May and June, 2004). Over the three-month period, the shorelines from September and November (2004) are further landwards than the average shoreline. The difference in shoreline position is of $80 \mathrm{~m}$ on average, reaching $100 \mathrm{~m}$ at their widest point location.

The large shoreline change is probably best explained by the presence of three hurricanes that passed close to the area: TS Bonnie and H Charley occurred during the first two weeks of August (Table 1), while Ivan took place 13 days before the SDS from September. 


\section{COASTAL ENGINEERING 2012}

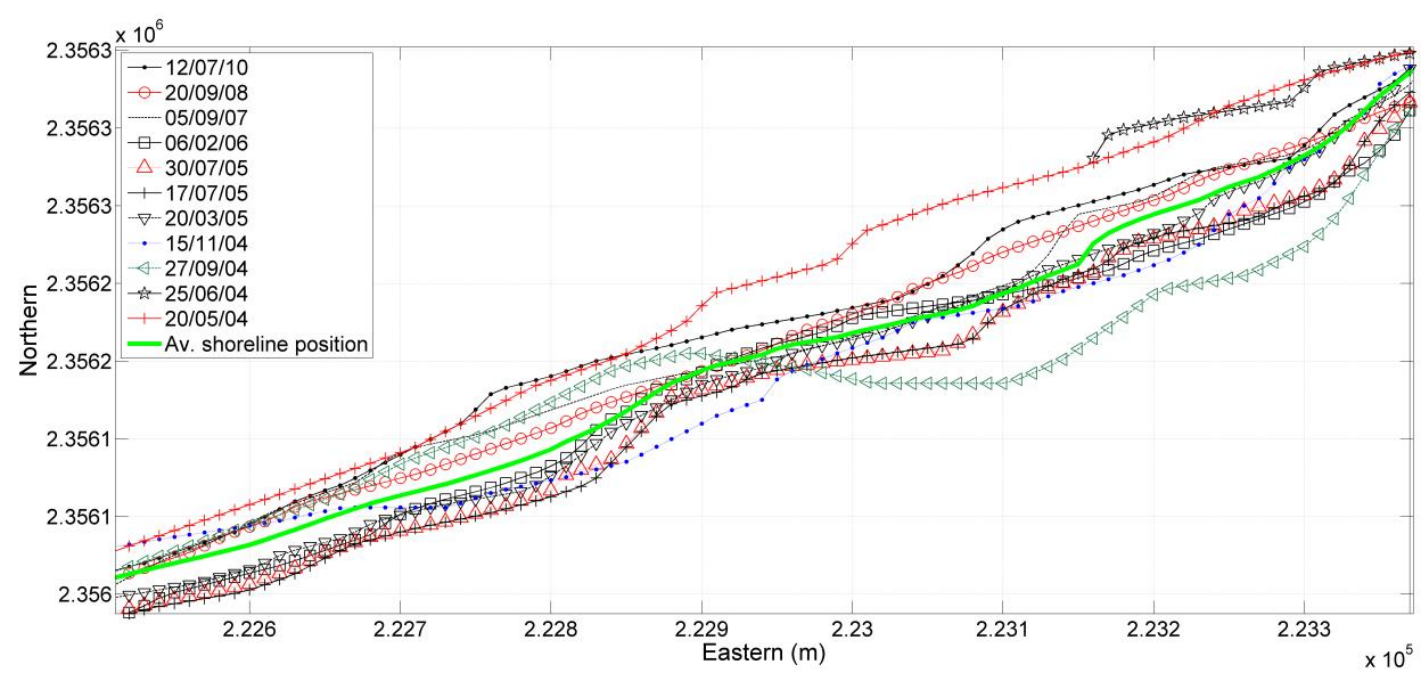

Figure 4. Shoreline positions of the available SDSs during December 2003 to July 2010 for segment 3 for Progreso, Yucatán. The shorelines shown are the mean location within the confidence bounds. The SDS from June $\mathbf{2 0 0 5}$ only covers part of the segment due to the availability of satellite images.

The wind velocities in July and August remained within the typical ranges ( $<12 \mathrm{kmh}^{-1}$, E-SE direction). Hurricane Ivan was the closest to Yucatán on the $14^{\text {th }}$ September (see appendix). Hurricane Ivan made its main landfall in Florida and after a few hours its maximum storm surge was recorded $(2 \mathrm{~m})$, producing an extensive overwash. The measured tides on the $14^{\text {th }}$ show a $50 \mathrm{~cm}$ residual during neap tides. This residual is probably due to a real surge. The precise magnitude of this surge is unknown due to the lack of consistency in the tidal record. However, a surge of 30 to $50 \mathrm{~cm}$ magnitude produced by Hurricane Ivan in Progreso is well within the expected range.

A change of $50 \mathrm{~cm}$ in the sea level could explain the large landward movement of the shoreline. The top of the beach slope in segment 3 is very shallow (0.003); only the rise in the sea level, without considering the wave set-up, could produce an overwash of at least $150 \mathrm{~m}$. Thus, the combined effect of a surge and waves could make possible the sand to be moved cross-shore and alongshore. The shoreline position from September 2004 has the furthest landwards position of all the studied shorelines. So, it seems plausible that the landwards shoreline position is related to Hurricane Ivan.

\section{Storms}

The shoreline change analysis using optical satellite images suggest that reversals in the dominant longshore sediment transport occurred during storms. The observed shoreline change of both segments (3 and 8) suggests that sand moved from west to east.

The western section of the SDS from $27^{\text {th }}$ September (2004) in segment 3 is seawards (Figure 4), whereas the eastern section is landwards relative to the average orientation of the shoreline. Interestingly the SDS from $15^{\text {th }}$ November (2004) has a smoother shape, suggesting an eastward sediment transport. In addition, the SDS from the same month (November) in beach segment 8 is on average 15 to $20 \mathrm{~m}$ seawards of the $27^{\text {th }}$ September SDS (Figure 5). During the winter season, storms with SW to $\mathrm{W}$ wind direction are commonplace, in contrast to the dominant direction during the remainder of the year. Such a change in the wind direction affects the approaching angle of the waves into the shore, and thus the longshore sediment transport. The longshore sediment flux is greater with high-angle waves (Komar 1998). So, high-angle waves from the SW would have produce a $20 \mathrm{~m}$ of seaward movement of the shoreline.

Due to the lack of data there is no certainty of the environmental conditions between $27^{\text {th }}$ September and $15^{\text {th }}$ November. However the relevance of this comparison is the potential use of SDSs for deduction of the coastal processes involved. When a better temporal spacing is being assessed, and 


\section{COASTAL ENGINEERING 2012}

information such as the wave height and direction is available, it would be possible to infer the coastal processes involved over a large geographical scales $(>10 \mathrm{~km})$.

\section{Calm}

The SDSs from $4^{\text {th }}$ April (only covering segment 8 ), $20^{\text {th }}$ March and $17^{\text {th }}, 30^{\text {th }}$ July (2005) are very close to each other $(<5 \mathrm{~m})$, and about $10 \mathrm{~m}$ landwards from the average shoreline in both segments 3 and 8 (Figures 4 and 5). During the calm season, overall the wind speed is very low $\left(<5 \mathrm{~km}^{*} \mathrm{~h}^{-1}\right)$, so no large changes in the shoreline are expected to take place. The fact that these three SDSs are so close to each other, on one hand gives confidence in the shoreline location found using optical satellite images, and on the other hand suggests that little recovery after Hurricane Ivan had occurred, making people living on the coast more vulnerable to the impact of a subsequent cyclone or storm.

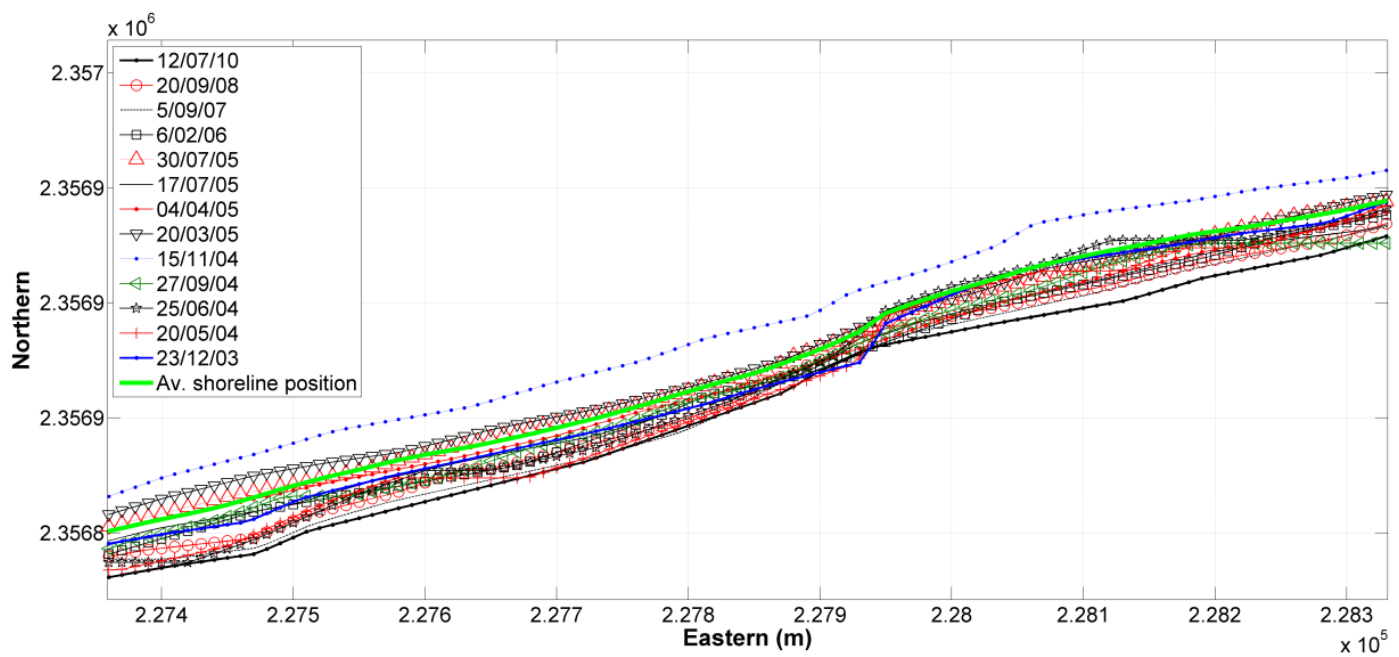

Figure 5. Shoreline positions of the available SDSs during December 2003 to July 2010 for segment 8 for Progreso, Yucatán.

\section{Inter-annual shoreline change}

The SDS from $6^{\text {th }}$ February 2006 is landwards at approximately $10 \mathrm{~m}$ from the average shoreline in segment 3. In contrast, the SDSs from years 2007, 2008 and 2010 from the same segment (3) are seawards by 6,7 and $18 \mathrm{~m}$ on average from the average shoreline. The seawards shoreline movement shows a recovery over time that tends towards full recovery to the seawards position observed on $20^{\text {th }}$ May 2004 (Figure 4).

In contrast, the shoreline change assessment suggests an overall landwards movement over time in segment 8 (Figure 5). The location from the SDS from $6^{\text {th }}$ February (2006) is $7 \mathrm{~m}$ landwards of the average shoreline, rather than seawards as observed in the SDS from $15^{\text {th }}$ November (2004). In addition, the shoreline location from 2007, 2008 and 2010 are landwards (10 to 20m) of the average shoreline.

The seawards location of the SDS from $15^{\text {th }}$ November in 2004 could be related to the frequency, direction and intensity of storms during winter. Unfortunately there is no available long time series for the study area that could help to understand the environmental conditions in winter (2005) which could have produced a landwards movement rather than a seawards movement.

To explore whether the shoreline position has moved landwards over time, the alongshore average of the northerly position was assessed during the studied period of time. Figure 6 shows that there is a large (>30m) shoreline movement from November (2004) to March (2005), period which corresponds from winter season to the calmest season of the year. 


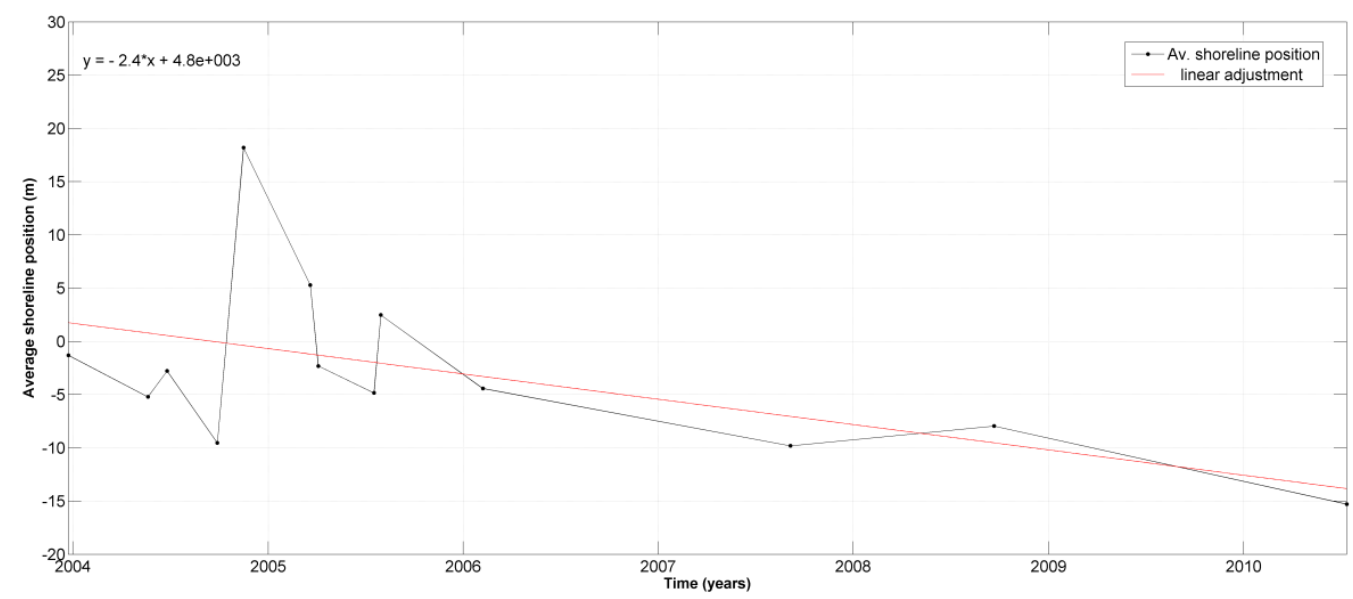

Figure 6. Average shoreline of beach segment 8 superimposed with the adjusted line. The equation of the adjusted line is: $y=-2.4^{\star} x+4800$, with a coefficient of determination $\left(r^{2}\right)$ of 0.3 .

The slope of the adjusted line is negative (-2.4), which suggests a shoreline retreat during the studied period of time in segment 8 . The temporal spacing of the images does not cover all the seasons and years, but it is a mix between SDSs from different seasons and different years. Crowell et al (1991) and Leatherman and Douglas (2003) have previously highlighted that the investigation of the seasonal variability is also very important to asses when estimating shoreline change in the long-term. The relatively small coefficient of determination $\left(r^{2}=0.3\right)$ of the lineal adjustment shows that the shoreline position depend on other variables that are not included in this analysis. Factors such as the gradients of sand, the incident wave height, frequency of extreme events, human modification, and seasonality are essential factors to understand the shoreline change over time. However, our results highlight that the technique used in here allows estimation of rates of change even when using a combination of widely spaced and frequent images.

The beach width in segment 8 is narrower than $25 \mathrm{~m}$, has a more northerly orientation than segment 3 , and does not have dunes and coastal vegetation (Table 2). Furthermore, this coastal area is widely populated with houses located very close to the shoreline. The shoreline orientation is relevant because has a direct effect into the approaching angle of the waves and thus the gradients of sand. Furthermore, as the work from Appendini et al (2012) shows, the potential longshore sediment transport in Yucatán coastline seems to be very sensitive to small variations of the shoreline orientation. These beach characteristics increase the vulnerability to coastal erosion in presence of a cyclone or a storm of segment 8 .

Although our results revealed a generalised shoreline retreat in Progreso, it remains possible that the shoreline retreat is due to the fact that most of the assessed SDSs (10 of 13) are from the hurricane and storm season. However, better spaced SDSs would overcome this problem and our analysis shows the potential use of our method to provide accurate estimates of rates of shoreline change and the forecasting of shoreline change for coastal management purposes.

Figure 7 shows a diagram with the estimated rates of change for each beach segment. The information presented in this diagram provides guidance for coastal managers and coastal scientists to ensure safety of people and their properties. In addition, this type of information allows identification of beach segments that have experienced rapid changes with storms, such as segment 3, while others show slow but constant movement as for example segment 8 . 


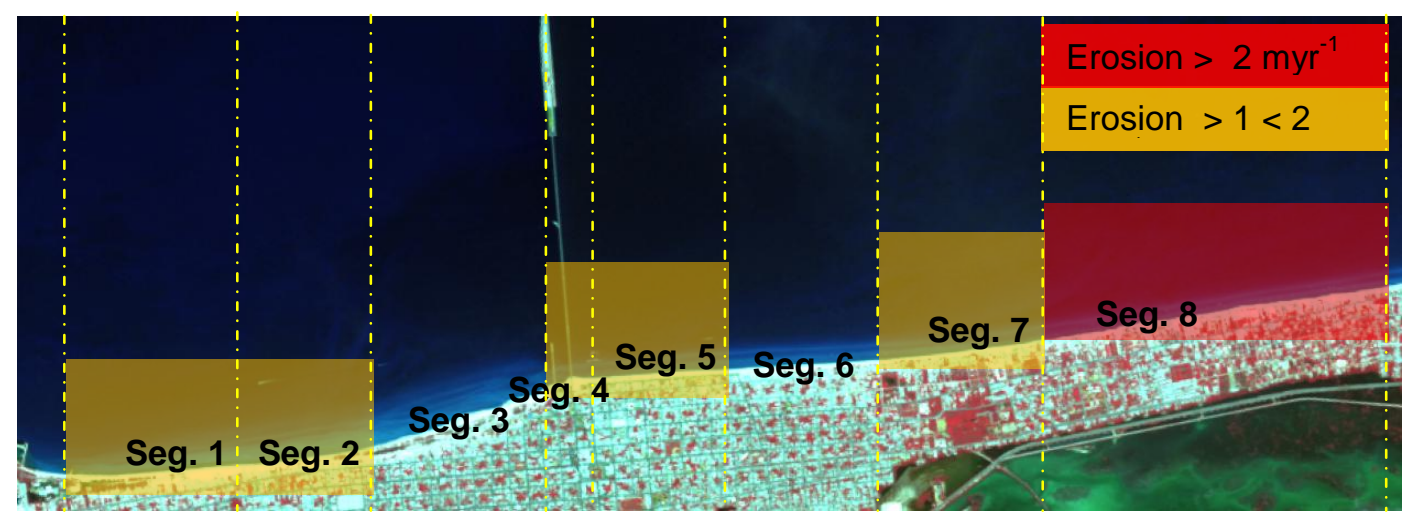

Figure 7. Estimated rates of change over a six-year period in Progreso, Yucatán. The rate of change was assessed using the average shoreline of each beach segment over the studied period of time.

\section{CONCLUSIONS}

Optical satellite images can produce accurate estimations $(<10 \mathrm{~m})$ of shoreline change covering large spatial scales $(>15 \mathrm{~km})$, as well as short ( $<1$ year) and long ( $>5$ years) temporal scales. Furthermore, rates of change can be estimated, demonstrating their utility for shoreline change studies, as this research shows using Progreso as a case of study.

The shoreline location of SDS from the same season but from different years is consistent, giving confidence that the interpretation of different positions of SDS shows real changes between seasons.

The beach located west of the pier (segment 3) has the largest and most rapid changes in shoreline position associated with Hurricane Ivan. However, the recovery of this segment is shown to be very slow and returning to the pre-hurricane seaward position may take several years.

An open, more northerly oriented stretch of coastline, segment 8, shows a consistent landward movement, with no recovery of its shoreline location between December 2003 and July 2010. In addition, the shoreline location of 2010 is approximately $20 \mathrm{~m}$ further landwards than the average shoreline. Therefore, the monitoring of this beach segment is recommended to identify whether this erosion continues over time.

\section{ACKNOWLEDGMENTS}

I would like to acknowledge to the British Society of Geomorphology for the support to attend the ICCE, as well as CONACyT who funded me during the $\mathrm{PhD}$ studies. 


\section{APPENDIX}

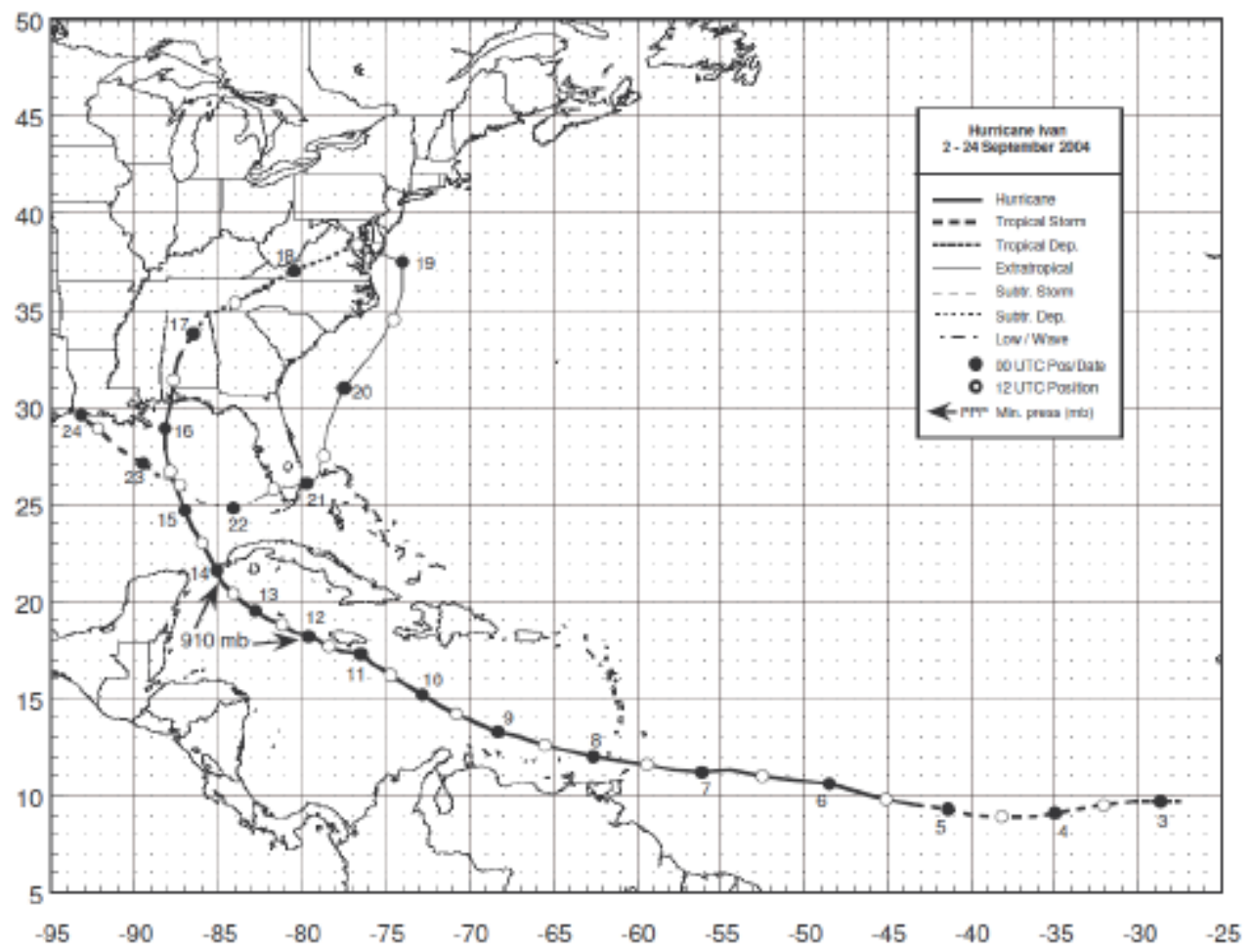

Figure 1. Track of Hurricane Ivan. The image is from NHC (2010). 


\section{COASTAL ENGINEERING 2012}

\section{REFERENCES}

Christian M. Appendini, Paulo Salles, E. Tonatiuh Mendoza, José López and Alec Torres-Freyermuth. 2012. Longshore Sediment Transport on the Northern Coast of the Yucatán Peninsula, Journal and Coastal Research. In-Press.

AXIS. 2008. Reporte de resultados de las campañas de monitoreo realizadas como parte del programa de seguimiento del proyecto: Estabilización de la duna costera mediante tubos geotextiles, para industria salinera de Yucatán, S.A de C.V., en las Coloradas, Yuc. Technical report, AXIS.

Chen, L. and Rau, J. Y. 1998. Detection of shoreline changes for tideland areas using multi-temporal satellite images, International Journal of Remote Sensing 19(17), 3383-3397.

Crowell, M., Leatherman, S. P. and Buckley, M. K. 1991. Historical shoreline change: Error analysis and mapping accuracy, Journal of Coastal Research 7(3), 839-852.

Dinesh-Kumar, P. K., Gopinath, G., Laluraj, C., Seralathan, P. and Mitra, D. 2007. Change Detection Studies of Sagar Island, India, using Indian Remote Sensing Satellite 1c Linear Imaging Self-Scan Sensor III Data, Journal of Coastal Research 23(6), 1498-1502.

Douglas, B., Kearney, M. S. and Leatherman, S. P. 2001. Sea Level Rise: History and Consequences, International Geophysics Series 75.

FitzGerald, D. M., Fenster, M. S., Argow, B. and Buynevich, I. V. 2008. Coastal impacts due to sealevel rise, Annu. Rev. Earth Planet. Sci. 36, 601-647.

Foody, G.M., Muslim, A.M. and Atkinson, P.M. 2005. Super-resolution mapping of the waterline from remotely sensed data, International Journal of Remote Sensing. 26(24), 5381-5392.

Frihy, O. and Lotfy, M. F. 1997. Shoreline changes and beach-sand sorting along the northern Sinai coast of Egypt, Geo-Marine Letters 17, 140-146.

García-Rubio, Gabriela. Evaluation of Shoreline Change using Optical Satellite Images, Case Study of Progreso, Yucatán. PhD thesis. University of Plymouth, United Kingdom.

Gutierrez, B. T., Plant, N. G. and Thieler, E. R. 2011. A bayesian network to predict coastal vulnerability to sea level rise, Journal of Geophysical Research. 116, 1-15.

Intergovernmental Panel on Climate Change. 1990. Policymaker's: Summary of the Potential Impacts of Climate Change report from working group II to the intergovernmental panel on climate change. Technical report, Intergovernmental Panel on Climate Change.

Komar. 1998. Beach Processes and Sedimentation. $2^{\text {nd }}$ edition. Prentice-Hall, USA, 544 pp.

Leatherman, S. and Douglas, B. 2003. Sea level and coastal erosion require large scale monitoring, American Geophysical Union 84(2), 13-20.

Li, R., Di, K. and Ma, R. 2003. 3-D Shoreline Extraction from IKONOS Satellite Imagery, Marine Geodesy 26, 107-115.

Li, R., Deshpande, S., Niu, X., Zhou, F., Di, K. and Wu, D. 2008. Geometric integration of aerial and high-resolution satellite imagery and application in shoreline mapping, Marine Geodesy 31, 143159.

Liu, H. and Jezek, K. 2004. Automated extraction of coastline from satellite imagery by integrating Canny edge detection and locally adaptive thresholding methods, International Journal of Remote Sensing 25(5), 937-958.

Mariño-Tapia, I. 2010. pers.comm., CINVESTAV-Merida, Researcher from Oceanography Physics in CINVESTAV-Merida.

Mason, D., Davenport, I. and Robinson, G. 1995. Construction of an inter-tidal digital elevation model by the water-line method, Geophysical Research Letters 22(23), 3187-3190.

Meyer-Arendt, K. J. 2001. Recreational development and shoreline modification along the north coast of Yucatán, México, Tourism Geographies 3(1), 87-104.

Muslim, A.M., Foody, G.M. and Atkinson, P.M. 2006. Localized soft classification for superresolution mapping of the shoreline, International Journal of Remote Sensing 27(11), 2271-2285.

National Hurricane Center (NHC). 1988. Hurricane Gil. Technical report, National Weather Advice, NOAA.

National Hurricane Center (NHC). 2010. Weather National Advicer, NOAA, http://www.nhc.noaa.gov/. URL: http://www.nhc.noaa.gov/

Robinson, I. S. 2004. Measuring the Oceans from Space. The principles and methods of satellite oceanography, Springer, Praxis, Germany.

Vitousek, P. M., Mooney, H. A., Lubchenco, J. and Melillo, J. M. 1997. Human Domination of Earth's Ecosystems, Science 277(5325), 494-499. 
Wang, C., Zhang, J. and Ma, Y. 2010. Coastline interpretation from multispectral remote sensing images using an association rule algorithm, Int. J. Remote Sensing 31(24), 6409-6423.

White, K. and El-Asmar, H. M. 1999. Monitoring changing position of coastlines using Thematic Mapper imagery, an example from the Nile Delta, Geomorphology 29, 93-105. 